\title{
Medalhas e Menção Honrosa na XV Olimpíada Ibero-Americana de Química
}

Mais uma vez, os estudantes de química portugueses viram o seu desempenho na Olimpíada Ibero-americana de Química recompensado com medalhas e menção honrosa. Assim, a delegação portuguesa regressou a Portugal com uma Medalha de Prata, uma Medalha de Bronze e uma Menção Honrosa na bagagem.

A Medalha de Prata foi conquistada por Gonçalo Vitorino Bonifácio, da ES José Saramago (Mafra), enquanto Jorge Pedro Martins Nogueiro, finalista da Escola Secundária Emídio Garcia, de Bragança, obteve a Medalha de Bronze. Marta Aguiar, da ES Homem Cristo em Aveiro, não atingiu as medalhas, mas o seu desempenho meritório foi reconhecido pelo Júri com a atribuição de uma das Menções Honrosas desta competição.

De referir que Jorge Pedro Martins Nogueiro já tinha obtido uma menção honrosa na $42^{a}$ Olimpíada Internacional de Química, que se realizou em Tóquio, no final do passado mês de Julho, tal como foi noticiado no número anterior deste Boletim.

A preparação dos participantes das Olimpíadas Internacionais e nas Olimpíadas Ibero-Americanas de Química está sedeada no Departamento de Química da Universidade de Aveiro desde 2002 e conta com a colaboração de uma equipa alargada.

Neste ano lectivo, a preparação - que se estendeu de Outubro de 2009 a Setembro de 2010 - teve a participação dos docentes do Departamento de Química Maria Clara Magalhães, Diana Pinto, Amparo Faustino, Graça Marques e Rita Ferreira. Esta equipa contou ainda com a colaboração de Ana Seca (docente da Universidade dos Açores) e de Alzira Rebelo (docente do Colégio dos Carvalhos). A colaboração da Prof. Alzira Rebelo e do Colégio dos Carvalhos - que acoIheu os alunos nos seus laboratórios - foi particularmente relevante na preparação dos alunos em técnicas laboratoriais básicas.

De acordo com os docentes que acompanharam a equipa (mentores), Maria Clara Magalhães e Diana Pinto, da Universidade de Aveiro, "é evidente que a experiência adquirida nos anos anteriores torna possível optimizar o tempo de preparação dos alunos", mas essa vantagem foi particularmente potenciada pelas "muitas horas de estudo e de entrega desta equipa".
Esta $15^{a}$ edição da Olimpíada IberoAmericana de Química decorreu na Cidade do México, México, de 22 a 29 de Outubro e juntou 52 finalistas do ensino secundário de 13 países iberoamericanos: Argentina, Bolívia, Brasil, Colômbia, Costa Rica, Cuba, Espanha, Guatemala, México, Perú, Portugal, Uruguai e Venezuela. Portugal foi o país organizador da competição em 2006 (na Universidade de Aveiro) e poderá voltar a sê-lo em 2013.

As Olimpíadas de Química são uma actividade promovida pela Sociedade Portuguesa de Química (www.spq.pt) com o patrocínio do Ministério da Educação e que visa:

I - dinamizar o estudo e ensino da Química nas Escolas Básicas e Secundárias,

II - proporcionar a aproximação entre as Escolas Básicas e Secundárias e as Universidades, e

III - despertar o interesse pela Química, cativando vocações para carreiras científico-tecnológicas entre os estudantes.

PRC, MCM

\section{Grupo de Químicos Jovens - Actividades Para 2011}

Durante o ano de 2010, o Grupo de Químicos Jovens (GQJ) esteve envolvido em várias actividades que muito contribuíram para dinamizar e aproximar a comunidade de jovens químicos portugueses. Destas actividades, salientamos o 2nd Portuguese Young Chemists Meeting (2PYCheM) que se realizou em Abril de 2010, na Universidade de Aveiro, e contou com a presença de aproximadamente 240 Químicos Portugueses e a atribuição do Prémio Químicos Jovens/Gradiva 2010 (PYCA) a Joana Barata e David Marçal, premiando assim a excelência do trabalho desenvolvido ao longo dos seus doutoramentos.
Em 2011, o GQJ irá apostar na dinamização de actividades que decorrerão exclusivamente online, dando primazia às secções, anteriormente divulgadas neste Boletim, JobChem e ChemRUS.

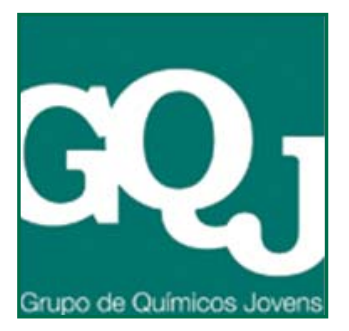

JobChem - Este espaço está dividido em duas componentes:
1) Compilação de motores de busca Nacionais e Internacionais de ofertas de emprego na área da Química;

2) Anúncios com oferta directa de bolsas ou empregos por parte de entidades públicas ou privadas.

Em especial, e relativamente à segunda componente, o balanço do primeiro ano de funcionamento é bastante positivo. No entanto, gostaríamos que no próximo ano a adesão fosse ainda maior, permitindo que esta secção se estabeleça como uma compilação de bolsas e empregos que possa ser representativa das ofertas existentes a nível Nacional (tendo-se também já 